\title{
Identification at the onset of luteolysis of follicles capable of ovulation in the ewe
}

\author{
C. G. Tsonis, L. P. Cahill*, R. S. Carson and J. K. Findlay \\ Medical Research Centre, Prince Henry's Hospital, Melbourne, Victoria 3004 and \\ ${ }^{*}$ Department of Agriculture, Animal Research Institute, Werribee, Victoria 3030, Australia
}

\begin{abstract}
Summary. Follicles of various sizes at the surface of the ovary were ablated by electrocautery at the time of cloprostenol-induced luteolysis in ewes and the interval from cloprostenol treatment to the onset of the LH surge determined as an index of the time from luteolysis to ovulation. When follicles $2-4 \mathrm{~mm}$ or $>4 \mathrm{~mm}$ diameter remained in the ovaries, the interval from cloprostenol treatment to the onset of the LH surge was similar to that in sham-operated (control) ewes $(55-60 \mathrm{~h}$ ), whereas when the only follicles remaining were $<2 \mathrm{~mm}$, the interval was extended by $24 \mathrm{~h}(P<0.05)$. This study demonstrates that follicles capable of ovulating can be selected from those $\geqslant 2 \mathrm{~mm}$ diameter at luteolysis, emphasizing the flexibility of the sheep ovary in its final selection of the ovulatory follicle.
\end{abstract}

\section{Introduction}

In the sheep ovary, the time taken for a primordial follicle to develop into a preovulatory follicle is estimated to be about 6 months. Most of this growing time is spent in the preantral stage, but once a follicle has formed an antrum it only requires 33-43 days to reach the preovulatory stage (Turnbull, Braden \& Mattner, 1977; Cahill \& Mauléon, 1980). There is good evidence to suggest that follicles are continuously developing and that most stages of growth are represented in the ovary at any one time (Brand \& de Jong, 1973). Land (1973) and Findlay \& Cumming (1977) concluded from studies on the effects of unilateral ovariectomy in the sheep that the number of eggs to be ovulated is finally determined within the 3 days immediately preceding the onset of oestrus, i.e. during luteolysis. Other evidence suggests that the final selection of the ovarian follicle(s) destined to ovulate is from a pool of small follicles (2-4 mm diameter) present at the time of luteolysis (Smeaton \& Robertson, 1971; Bhérer, Dufour \& Matton, 1976; McNatty, 1982; McNatty et al., 1982).

The aim of these experiments was to determine the size of follicles at the onset of luteolysis which are capable of being selected as the ovulatory follicle(s) in the ewe.

\section{Materials and Methods}

Animals. All animals were Corriedale ewes aged 5-6 years. The experiments were conducted in March and May during the breeding season (February-June) at the Animal Research Institute, Werribee, Victoria.

The ovarian cycles of 20 ewes in Exp. 1 and 36 ewes in Exp. 2 were synchronized by treatment with progestagen-impregnated vaginal sponges ( $30 \mathrm{mg}$ Chronogest: Intervet, Angers, France) for 14 days, and oestrous activity (Day 0 ) was detected by means of vasectomized rams fitted with 
marking crayons. On Day 12 of the synchronized cycle, anaesthesia was induced in all the ewes with pentobarbitone sodium (Parke, Davis, Australia) and maintained with halothane (ICI, Australia) during mid-ventral laparotomy. The uterus was exposed and each ovary was inspected carefully. The numbers of corpora lutea and number and diameter of follicles were recorded for each ewe before ablation by electrocautery. The diameter, to the nearest $0.5 \mathrm{~mm}$, of the follicles on the surface of each ovary was determined by comparison with interchangeable electrocautery tips, each consisting of a stainless-steel angled rod with a ball of a calibrated size attached to the end.

Experiment 1 . Twenty ewes were randomly divided into 3 groups. Ewes in Group 1 (control) underwent laparotomy only. In Groups 2 and 3 , all follicles $\geqslant 2 \mathrm{~mm}$ and $\geqslant 4 \mathrm{~mm}$ diameter respectively were ablated. Immediately after surgery ewes were given $125 \mu \mathrm{g}$ (i.m.) cloprostenol (Estrumate: ICI) to induce luteolysis. Ewes were penned with 2 vasectomized rams to detect oestrus.

Samples of blood $(8-10 \mathrm{ml})$ were collected by jugular venepuncture into heparinized syringes at 3-h intervals, from 12 to $110 \mathrm{~h}$ after cloprostenol administration, to monitor the time of onset of the LH surge. Samples were then collected every 2 nd day for plasma progesterone determination to monitor luteal function until the next oestrus. The blood was centrifuged within $30 \mathrm{~min}$ of collection and the plasma was decanted and stored at $-15^{\circ} \mathrm{C}$. Plasma samples were then assayed for progesterone and $\mathrm{LH}$.

Laparoscopies were performed under pentobarbitone sodium anaesthesia according to the method of Roberts (1968), on all 20 ewes on Day 10 or 12 of the ensuing oestrous cycle to establish the number of corpora lutea.

Experiment 2. Thirty-six ewes were randomly divided into 5 groups. Control ewes (Group 1) had non-follicular (stromal) tissue electrocauterized, carefully avoiding any visible follicles and luteal structures. In the treatment groups, follicles $\geqslant 2 \mathrm{~mm}$ (Group 2), $\geqslant 4 \mathrm{~mm}$ (Group 3), $\geqslant 2 \mathrm{~mm}$ and $\leqslant 4 \mathrm{~mm}$ (Group 4 ) or $\leqslant 4 \mathrm{~mm}$ (Group 5 ) were ablated. Immediately after surgery ewes were given $125 \mu \mathrm{g}$ cloprostenol and penned with 4 vasectomized rams to detect oestrus. Samples of blood were collected at 2-h intervals, from 40 to $120 \mathrm{~h}$ after PG injection, and then every $2 \mathrm{nd}$ day until the next oestrus. LH and progesterone were measured in the plasma samples.

Hormone assays. Progesterone concentrations were determined by radioimmunoassay (WHO Matched Assay Reagents) after extraction of $200 \mu \mathrm{l}$ plasma with $2 \mathrm{ml}$ diethyl ether. Corrections for losses were not made because the extraction efficiency was in the range of $90-95 \%$. The antiserum was specific for progesterone, with minor cross-reaction with other steroids ( $5 \alpha$-dihydroprogesterone, $7 \% ; 17 \alpha$-hydroxyprogesterone, $1 \% ; 20 \alpha$-dihydroprogesterone, $2.7 \%$ ). The sensitivity of the assay was $11.7 \mathrm{fmol} /$ tube. The intra-assay coefficient of variation (CV) for 10 consecutive assays was $<15 \%$ over the range $33-1926 \mathrm{fmol} /$ tube (minimum $4.6 \%$ ) and the interassay CV was $8.5 \%$.

$\mathrm{LH}$ concentrations were measured using the double-antibody radioimmunoassay technique of Lee et al. (1976), with reference standard NIH-LH-S18 (biopotency 1.03 $\times$ NIH-LH-S1). The mean sensitivity of 10 consecutive assays was $0.043 \mathrm{ng} /$ tube. The intra-assay CV was $<10 \%$ over the range $2-35 \mathrm{ng} / \mathrm{ml}$ (minimum 5.6\%) and the interassay CV was $10.9 \%$.

All radioimmunoassay data were processed using the computer programme described by Burger, Lee \& Rennie (1972).

Statistical analysis. The LH surge was defined as when $\mathrm{LH}$ was $>10 \mathrm{ng} / \mathrm{ml}$ for $>6 \mathrm{~h}$, and the onset when concentrations first exceeded $10 \mathrm{ng} / \mathrm{ml}$ (Wright, Geytenbeek, Clarke \& Findlay, 1980). The interval from cloprostenol administration to the onset of the $\mathrm{LH}$ surge was compared between groups by one-way ANOVA and Duncan's F test. In Exp. 2, the data were transformed to logarithms to obtain homogeneity of the variances. Data of Exp. 1 were converted to mean $\pm 95 \%$ confidence interval to permit direct comparison with Exp. 2. Control groups in each experiment were compared using Student's unpaired $t$ test. 


\section{Results}

\section{Experiment 1}

The interval from cloprostenol administration to the onset of the LH surge was significantly longer in Group 2 than in Group 1 (controls) and Group $3\left(\mathrm{~F}_{2,16}=5.49, P<0.05\right)$ (Table 1, Textfig. 1a). There was no effect of treatment on the ovulation rate (Group 1, $7 \mathrm{CL} / 7$ ewes; Group 2, $9 / 8$; Group 3, 5/5), the length of the luteal phase, as indicated by both the profiles of plasma progesterone (data not shown) and the concentrations on Day 10 (Table 2), or the length of the subsequent cycle (Group 1, 17.8 \pm 0.4 days; Group 2, $17.3 \pm 0.3$ days; Group 3, $17.6 \pm 0.4$ days from the LH surge to next oestrus). All ewes except 2, both in Group 2, had functional CL as indicated by their appearance at laparoscopy and the profiles of plasma progesterone during the

(a) Exp. 1

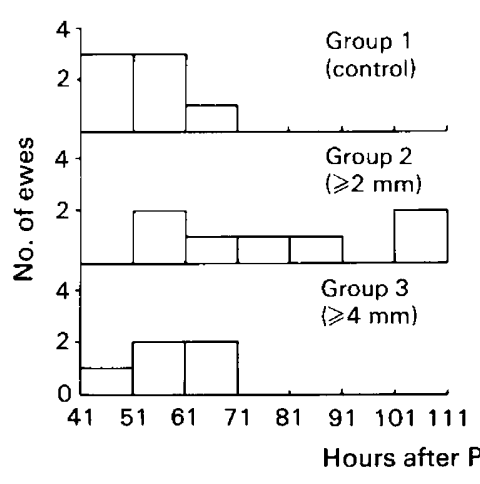

(b) Exp. 2

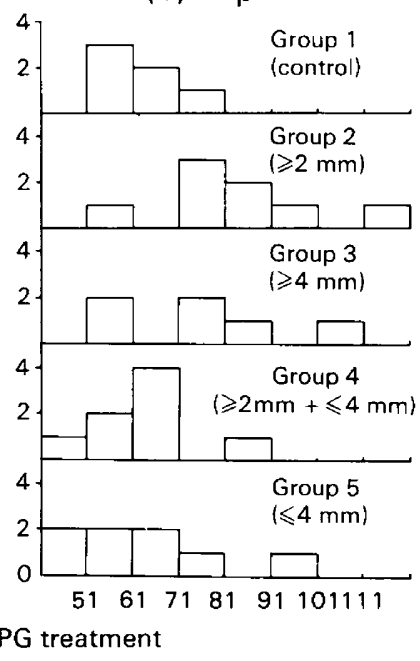

Text-fig. 1. Distribution of ewes amongst time intervals from cloprostenol administration to the onset of the LH surge in ewes in which follicles of various sizes were ablated at the time of induced luteolysis in (a) Exp. 1 and (b) Exp. 2.

Table 1. The interval from cloprostenol administration to the onset of the $\mathrm{LH}$ surge $(\mathrm{h})$ in control ewes and ewes in which follicles of various sizes were ablated at induced luteolysis on Day 12 of the cycle

\begin{tabular}{|c|c|c|c|c|c|}
\hline \multirow[b]{2}{*}{ Experiment } & \multicolumn{5}{|c|}{ Group } \\
\hline & $\begin{array}{c}1 \\
\text { (control) }\end{array}$ & $(\geqslant 2 \mathrm{~mm})$ & $(\geqslant 4 \mathrm{~mm})$ & $\begin{array}{c}4 \\
(\geqslant 2 \mathrm{~mm}+\leqslant 4 \mathrm{~mm})\end{array}$ & $\begin{array}{c}5 \\
(\leqslant 4 \mathrm{~mm})\end{array}$ \\
\hline $1+$ & $\begin{array}{c}54 \cdot 2 \\
(53 \cdot 4-55 \cdot 1) \\
(7)\end{array}$ & $\begin{array}{c}75 \cdot 4^{*} \\
(70 \cdot 7-80 \cdot 4) \\
(7)\end{array}$ & $\begin{array}{c}58 \cdot 5 \\
(57 \cdot 6-59 \cdot 4) \\
(5)\end{array}$ & - & - \\
\hline 2 & $\begin{array}{c}60 \cdot 0 \\
(58 \cdot 8-61 \cdot 3) \\
(6)\end{array}$ & $\begin{array}{c}84 \cdot 6 \ddagger \\
(78 \cdot 1-91 \cdot 7) \\
(8)\end{array}$ & $\begin{array}{c}75 \cdot 5 \\
(71 \cdot 2-80 \cdot 2) \\
(6)\end{array}$ & $\begin{array}{c}61 \cdot 2 \\
(59 \cdot 6-62 \cdot 5) \\
(8)\end{array}$ & $\begin{array}{c}59 \cdot 6 \\
(56 \cdot 1-63 \cdot 3) \\
(8)\end{array}$ \\
\hline
\end{tabular}

Values are geometric means $(95 \%$ confidence interval) and the number of sheep in each group is shown in parentheses.

* Group 2 compared with Groups 1 and 3; $P<0.05$.

$\dagger$ One ewe in Group 2 was excluded from analysis because it failed to ovulate.

$¥$ Group 2 compared with Groups 1,4 and $5 ; P<0.05$. 
Table 2. Plasma progesterone concentrations ( $\mathrm{nmol} / \mathrm{l}$ ) on Day 10 of the oestrous cycle in control ewes and ewes in which follicles of various sizes had been ablated at induced luteolysis on Day 12 of the previous cycle

\begin{tabular}{|c|c|c|c|c|c|}
\hline \multirow[b]{2}{*}{ Experiment } & \multicolumn{5}{|c|}{ Group } \\
\hline & $\begin{array}{c}1 \\
\text { (control) }\end{array}$ & $(\geqslant 2 \mathrm{~mm})$ & $\left(\begin{array}{c}3 \\
4 \mathrm{~mm})\end{array}\right.$ & $(\geqslant 2 \mathrm{~mm}+\leqslant 4 \mathrm{~mm})$ & $\begin{array}{c}5 \\
(\leqslant 4 \mathrm{~mm})\end{array}$ \\
\hline 1 & $5 \cdot 4 \underset{(7)}{ \pm} 0 \cdot 5$ & $6.5 \pm 0.7$ & $7 \cdot 5 \pm 0.6$ & - & - \\
\hline 2 & $8 \cdot 0 \pm 0.6$ & $7 \cdot 9 \pm 0 \cdot 6$ & $8 \cdot 7 \pm 0 \cdot 7$ & $7 \cdot 4+0.5$ & $7 \cdot 6 \pm \frac{ \pm 0}{(8)} 0 \cdot 6$ \\
\hline
\end{tabular}

Values are mean \pm s.e.m. and the number of sheep in each group is shown in parentheses.

luteal phase. One ewe in Group 2 did not show oestrus or an LH surge within the period of observation; no $\mathrm{CL}$ was observed at laparoscopy and plasma progesterone concentrations remained $<0.5 \mathrm{nmol} / \mathrm{l}$. Because plasma concentrations of progesterone subsequently increased to $4.5 \mathrm{nmol} / 1$, it was deduced that this ewe ovulated about 18 days after cloprostenol administration. The other ewe in Group 2 had a normal LH surge (interval $87 \mathrm{~h}$ ) but a short luteal phase, and returned to oestrus 14 days after cloprostenol administration and subsequently ovulated.

\section{Experiment 2}

The interval from cloprostenol administration to the onset of the LH surge was significantly longer in Group 2 than in Groups 1 (controls), 4 and 5, but not Group $3\left(F_{4,31}=3.41, P<0.025\right.$; Table 1, Text-fig. 1b). Only 1 ewe in Group 2 failed to show oestrus or an LH surge within $120 \mathrm{~h}$, but all ewes had functional CL as indicated by the Day 10 progesterone levels (Table 2, Exp. 2) which did not differ between groups.

Ablation by electrocautery per se did not significantly influence the interval in either experiments. Firstly, the mean interval from cloprostenol administration to the onset of the LH surge in Group 1 of Exp. 1 (sham-operated) did not differ significantly from that in Group 1 of Exp. 2 (stroma cauterized, $t=-1 \cdot 33, P>0.05$ ). Secondly, there was no significant correlation between the number of follicles ablated per ewe and the interval from cloprostenol administration to the onset of the LH surge in Exp. $1(r=0 \cdot 12, \mathrm{~N}=12)$ or Exp. $2(r=-0 \cdot 15, \mathrm{~N}=30)$ (Text-fig. 2).

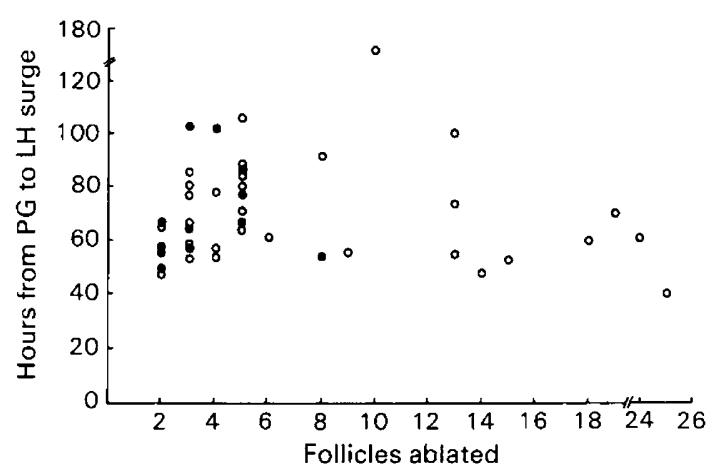

Text-fig. 2. The relationship between the number of follicles ablated per ewe and the interval from cloprostenol injection to the onset of the LH surge ( Exp. 1, $N=12 ; \bigcirc \operatorname{Exp} .2, N=30$ ). 


\section{Discussion}

Under the experimental conditions of this study, we have demonstrated that follicles capable of ovulating within the expected time from induced luteolysis to ovulation can come not only from a pool of small antral follicles 2-4 mm diameter (Smeaton \& Robertson, 1971; Bhérer et al., 1976; McNatty, 1982; McNatty et al., 1982), but also from follicles $\geqslant 4 \mathrm{~mm}$ diameter at luteolysis. Even if the only follicles present at luteolysis were $<2 \mathrm{~mm}$ diameter, these were able to ovulate and form functional corpora lutea but with a delay of approximately $24 \mathrm{~h}$. A delay in the interval after ablation of follicles of certain size, compared with sham-operated ovaries, would indicate that the follicles remaining in the ovary could not grow at a sufficiently fast rate to allow ovulation to occur at the expected time. It is therefore likely that follicles which remained after electrocautery at luteolysis, and which ovulated within the normal time, could have been selected as the ovulatory follicles in the normal cycle.

Our conclusion that follicles capable of ovulation can come from a wide range of size groups at luteolysis is supported by the results of studies in which follicles were marked with ink towards the end of an ovarian cycle. Smeaton \& Robertson (1971) observed that, in 1 ewe of 7 studied, 2 medium-large follicles marked with ink on Day 13 subsequently ovulated. Bhérer et al. (1976) observed that while the largest follicle marked on Day 14 subsequently ovulated, when there were twin ovulations the second ovulation resulted from a smaller unmarked follicle. Driancourt \& Cahill (1983) have marked follicles on ovaries of sheep from the same flock as those used in our study, and showed that the follicles that ovulated were derived from follicles of all sizes $\geqslant 2 \mathrm{~mm}$ diameter at the time of natural luteolysis. These results suggest that the ovary has great flexibility in selecting follicles for ovulation. In Exp. 2 ovulation occurred within the expected time irrespective of which group of follicles $\geqslant 2 \mathrm{~mm}$ diameter was ablated. The process which would allow such flexibility could be a decrease in the incidence of atresia so that follicles normally destined to become atretic would be prevented from doing so (McNatty et al., 1982), alterations in the mitotic index of granulosa cells and hence growth rates of follicles, or both (Cahill, Chamley \& Findlay, 1983).

We did not observe any significant changes in ovulation rate (Exp. 1) after ablation of follicles. Chupin \& Saumande (1981) found no difference in ovulation rate in the cow after ablation of all follicles $>2$ or $>8 \mathrm{~mm}$ diameter.

The hormonal events following induced luteolysis and the interval from induced luteolysis to the LH surge and ovulation in the controls are likely to be similar to that in the natural cycle (Chamley et al., 1972; Baird, Land, Scaramuzzi \& Wheeler, 1976). However, in the experimental groups ablation of follicles, especially all those $\geqslant 2 \mathrm{~mm}$ diameter, would probably lead to a decrease in ovarian and circulating oestradiol-17 $\beta$ and inhibin (Tsonis et al., 1983), a temporary maintenance or increase in the circulating concentration of FSH, and an increase in mitotic index of growing follicles similar to that observed after ablation of follicles in the luteal phase (Cahill et al., 1983). Whether these hormonal changes effect the selection of follicles or the growth of selected follicles as well is not known at present.

We thank Dr Wayne Chamley, Marc Driancourt, Bruce Doughton and Peter Langdon for skilled assistance and advice; Steve McPhee for the laparoscopies; Dr Leo Reichert Jr, NIH, and WHO for radioimmunoassay standards and reagents; and Julie Coleman for secretarial assistance. C.G.T. is a postgraduate scholar of the Australian Meat Research Committee and this project was supported by the Australian Meat Research Committee, the Australian Wool Research Trust Fund and National Health and Medical Research Council of Australia.

\section{References}

Baird, D.T., Land, R.B., Scaramuzzi, R.J. \& Wheeler, A.G. (1976) Endocrine changes associated with luteal regression in the ewe; the secretion of ovarian oestradiol, progesterone and androstenedione and uterine prostaglandin $F_{2 \alpha}$ throughout the oestrous cycle. J. Endocr. 69, 275-286. 
Bhérer, J., Dufour, J.J. \& Matton, P. (1976) Destińee des deux plus gros follicules des ovaries de brébis a là suite de la destruction du plus gros follicule et/ou de l'enlévement du corps jaune á deux moments du cycle. Can. J. Physiol. Pharmacol. 54, 7-11.

Brand, A. \& de Jong, W.H.R. (1973) Qualitative and quantitative micromorphological investigations of the tertiary follicle population during the oestrous cycle in sheep. J. Reprod. Fert. 33, 431-439.

Burger, H.G., Lee, V.W.K. \& Rennie, G.C. (1972) a generalised computer program for the treatment of data from competitive protein binding assays including radioimmunoassays. J. Lab. Clin. Med. 80, 302312.

Cahill, L.P. \& Mauléon, P. (1980) Influences of season, cycle and breed on follicular growth rates in sheep. $J$. Reprod. Fert. 58, 321-328.

Cahill, L.P., Chamley, W.A. \& Findlay, J.K. (1983) Hormonal control of follicles in the ovine follicular phase. Proc. Aust. Soc. Reprod. Biol. 15, 78, Abstr.

Chamley, W.A., Buckmaster, J.M., Cain, M.D., Cerini, J., Cerini, M.E., Cumming, I.A. \& Goding, J.R. (1972) The effect of prostaglandin $F_{2 \alpha}$ on progesterone, oestradiol and luteinizing hormone secretion in sheep with ovarian transplants. J. Endocr. 55, 253-263.

Chupin, D. \& Saumande, J. (1981) Effect of exogenous prostaglandin and/or estrogen on luteolysis after electrocauterization of the largest follicles at the end of the bovine estrous cycle. Theriogenology 16, 497 504.

Driancourt, M.A. \& Cahill, L.P. (1983) Preovulatory follicular events in sheep. Proc. Aust. Soc. Reprod. Biol. 15, 24, Abstr.

Findlay, J.K. \& Cumming, I.A. (1977) The effect of unilateral ovariectomy on plasma gonadotropin levels, estrus, and ovulation rate in sheep. Biol. Reprod. 17, 178-183.
Land, R.B. (1973) Ovulation rate of Finn-Dorset sheep following unilateral ovariectomy or chlorpromazine treatment at different stages of the oestrous cycle. $J$. Reprod. Fert. 33, 99-105.

Lee, V.W.K., Cumming, I.A., de Kretser, D.M., Findlay, J.K., Hudson, B. \& Keogh, E.J. (1976) Regulation of gonadotrophin secretion in rams from birth to sexual maturity. I. Plasma LH, FSH and testosterone levels. J. Reprod. Fert. 46, 1-6.

McNatty, K.P. (1982) Ovarian follicular development from the onset of luteal regression in humans and sheep. In Follicular Maturation and Ovulation, pp. 118. Eds R. Rolland, E. V. van Hall, S. G. Hillier, K. P. McNatty \& J. Schoemaker. Excerpta Medica, Amsterdam.

McNatty, K.P., Gibb, M., Dobson, C., Ball, K., Coster, J., Heath, D. \& Thurley, D.C. (1982) Preovulatory follicular development in sheep treated with PMSG and/or prostaglandin. J. Reprod. Fert. 65, 111-123.

Roberts, E.M. (1968) Endoscopy of the reproductive tract of the ewe. Proc. Aust. Soc. Anim. Prod. 7, 192194.

Smeaton, T.C. \& Robertson, H.A. (1971) Studies on the growth and atresia of Graafian follicles in the ovary of the sheep. J. Reprod. Fert. 25, 243-252.

Tsonis, C.G., Quigg, H., Lee, V.W.K., Leversha, L., Trounson, A.O. \& Findlay, J.K. (1983) Inhibin in individual ovine follicles in relation to diameter and atresia. J. Reprod. Fert. 67, 83-90.

Turnbull, K.E., Braden, A.W.H. \& Mattner, P.E. (1977) The pattern of follicular growth and atresia in the ovine ovary. Aust. J. biol. Sci. 30, 229-241.

Wright, P.J., Geytenbeek, P.E., Clarke, I.J. \& Findlay, J.K. (1980) Pituitary responsiveness to L.H-RH, the occurrence of oestradiol-17 $\beta$-induced LH-positive feedback and the resumption of oestrous cycles in ewes post partum. J. Reprod. Fert. 60, 171-176.

Received 2 August 1983 